\title{
Influence of Mineral Fertilizers on Winter Wheat Yield
}

\author{
Ksenia Moiseeva \\ ass. professor of General Biology Department, \\ Federal State Budgetary Educational \\ Institution of Higher Education \\ «Northern Trans-Ural State Agricultural University» \\ Tyumen, Russia \\ moiseeva.ks.@mail.ru
}

\author{
Alexander Karmatskiy \\ Ph.D. student \\ Federal State Budgetary Educational \\ Institution of Higher Education \\ «Northern Trans-Ural State Agricultural University» \\ Tyumen, Russia \\ turnmills@rambler.ru
}

\author{
Anastasia Moiseeva \\ Student \\ Federal State Budgetary Educational \\ Institution of Higher Education \\ «Northern Trans-Ural State Agricultural University» \\ Tyumen, Russia \\ anastasiya.moiseewa2010@yandex.ru
}

\begin{abstract}
The article considers the issue revealing the impact of slow-acting nitrogen fertilizers on the formation of leaf area and winter wheat productivity. A number of research was conducted in 2014-2017 in the forest-steppe zone of the Tyumen region, on leached chernozem, a predecessor is pure steam. In the period of earing the development of the leaf apparatus of winter wheat has been intensified by $0.18-4.73 \%$, with respect to the control (without fertilizers) and other compared variants. Concerning the structure of winter wheat yield, within the period of study, the third, fourth and sixth variants of the experiment are traced, in which the control variant (without fertilizers) was exceeded by the largest number of indicators to the yield structure. The yield in the third, fourth and fifth variants was close in value, respectively, 3.36-3.41 kilo/ha, which is higher by $0.27-0.32 \mathrm{kilo} / \mathrm{ha}$. The second option with the introduction of urea $(60 \mathrm{~kg} / \mathrm{ha}$ ai) appeared to be less effective: the average yield increase was $0.66 \%$ relative to the control. The yield of winter wheat, depending on the weather conditions of winter period, can vary from 2.20 to $4.58 \mathrm{t} / \mathrm{ha}$, with a yield increase of up to 0.51 kilo/ha, which can positively affect the economic efficiency of cultivation and distribution of this yield in the Northern foreststeppe of the Tyumen region. It was established that the highest yield increase compared with the control one was obtained in the sixth variant with fertilization including carbamide encapsulated according to "Si" technology.
\end{abstract} wheat

Keywords - mineral fertilizers, leaf area, crop yield winter

\section{INTRODUCTION}

The climatic and soil resources of the Tyumen region allow to cultivate winter wheat. On average for 40 years the yield of spring wheat was $14.4 \mathrm{c} /$ ha rather than winter wheat was 16.2 , which is by $1.8 \mathrm{c} /$ ha higher than the yield of spring wheat [1].

Improving the sustainability of grain production, increasing a gross harvest is considered to be one of the key elements in production. One of the components of the resource-saving technology in wheat growing is the use of mineral fertilizers [2-9].

At present, the State Agricultural University of the Northern Trans-Urals produces slow-acting nitrogenous fertilizers that have been gained with "Si" technology [10].

For three years in the experimental field of the Northern Trans-Urals the field experiment has been conducted aimed at studying the influence of the mineral fertilizers on the leaf area and winter wheat yield

\section{SuBJECTS AND Methods}

In this vein, the aim of the current research is to study the efficacy of slow-acting nitrogenous fertilizers on leaf area formation and winter wheat productivity.

The soil used in the experiment is leached chermozem, humus substance is $7.65-9.05 \%$ [11]. The experiment dealt with the standard sort of winter wheat "Novosibirskay 32", with six experiment variants to apply fertilizers according to the experiment agenda. A seed time is the first part of September. The periodicy of the experiment is quadruplex, a square of a field is $30 \mathrm{~m}^{2}$. Agro-equipment is conventional to be used for a culture in this zone. A predecessor is pure steam. Six variants have been studied:

- № 1 - control (without fertilizers); 
- № 2 - carbamide (60 kg/ha ai.)

- № 3 - carbamide encapsulated within "Si" technology (60 kg/ha ai.);

- № 4 - carbamide encapsulated within "Si" technology (30 kg/ha ai.);

- № 5 - 4 - carbamide encapsulated within "Si" technology (30 kg/ha ai.) + $\mathrm{KCl}$ (30 kg/ha ai.);

- № 6 - 4 - carbamide encapsulated within "Si" technology (60 kg/ha ai.) + $\mathrm{KCl}(30 \mathrm{~kg} / \mathrm{ha}$ ai. $)+\mathrm{P} 2 \mathrm{O} 5$ (40 kg/ha.ai.).

The fertilizers have been added simultaneously with seeding. All records and observations have been conducted in accordance with mainstream approaches; the results have been processed with a dispersion method [12].

\section{RESULTS}

The average annual air temperature and the amount of total precipitation contributed to the growth and the development of winter wheat under the conditions of the Northern foreststeppe of the Tyumen region. While doing the research, the temperature mode and a number of sediments during the growing season differed in different time/years in terms of the sum relating to active temperatures and moisture availability. Their distribution over the growing season was uneven, with a lack of precipitation due to air temperatures increase.

Thus, years 2014-2015 have been characterized by a harsh cold winter with a minimum temperature of January of $31.0^{\circ} \mathrm{C}$ that is below the average annual temperature by $3.30^{\circ}$ C. The same years had a very rainy summer; the precipitation fell exceeded the average annual number by $10 \mathrm{~mm}$. In general, during 2014-2015 years $153.1 \mathrm{~mm}$ of precipitation fell, this is $35 \mathrm{~mm}$ lower than the average rate.

2015-2016 years have been marked with warm winters, the air temperature varied from $-1.0{ }^{0} \mathrm{C}$ in daytime to -25.0 $32.0^{\circ} \mathrm{C}$ at night. In February, there was observed in the afternoon a sharp warming that was up to $+1.0^{\circ} \mathrm{C}$. Such an abnormal winter led to the partial death of winter wheat. The air temperature in the spring-summer period was almost at the level of the average annual value, which is $84.1^{\circ} \mathrm{C}$, the precipitation fell was $28 \mathrm{~mm}$ above the norm. This allowed us to seed in spring all-year-old grasses into winter wheat (peaoat mixture). In the third decade of July we harvested green mass.

2016-2017 years also have been characterized by warm summers with temperatures above the average annual rate of $2.0^{\circ}$ in July, and the precipitation was $11 \mathrm{~mm}$ below normal. The average annual precipitation in the zone of the experiment was $300 \mathrm{~mm}$, which is $29 \mathrm{~mm}$ higher the average rate. The most crop years were 2016-2017, because during the springsummer growing season, the optimal conditions were established for winter wheat yields growing; the sum of temperatures exceeded the average rate of the annual temperature by $10.4^{\circ} \mathrm{C}$.
Based on the weather conditions in the years of conducting the experiment, the winter-hardiness of plants was noted in 4.8-5.0 points in the first and third year of the experiment, in the second year the winter resistance was 2 points.

The photosynthetic activity of plants is the main process that determines the productivity of plants [13]. Mineral fertilizers had a positive effect on leaf surface. For 2014-2017 the sort "Novosibirskay 32" formed the largest leaf area in the earing phase, with the use of 6th variant, its value was 46.17 kilo $\mathrm{m} 2$ /ha, which is by 4.73 kilo $\mathrm{m} 2 /$ ha more compared with the control.

We noted that in the period of earing the development of a leaf area of winter wheat was intensified by $0.18-4.73 \%$, with respect to the control (without fertilizers) and other compared variants. In variant No. 1, there was noted a decrease in the leaf area by $2.92 \mathrm{kilo} \mathrm{m} 2 / \mathrm{ha}$.

The yield and elements of its structure are the main indicators determining the effectiveness of mineral fertilizers that are used to increase the productivity of the crop [14-15].

Field germination of plants in the years of the experimental study was $72-80 \%$, which is typical to the conditions of the Northern Trans-Urals. By harvesting time plants livability reached $82-89 \%$. The highest productive tillering potential was noted in the third, fourth and sixth variants of the experiment (1.8-1.9); in the other variants of the experiment the productive tillering potential were 1.6-1.7.

The height of the wheat plants on the sort under study varied depending on the variants of the experiment to be used. The highest plant height was noted in the second and sixth variants $-106 \mathrm{~cm}$; in the control variant this indicator was 100 $\mathrm{cm}$; the fourth variant was $2 \mathrm{~cm}$ higher; and the fifth one was 2 $\mathrm{cm}$ lower. The minimum height of the plants was noted in the third variant, it was $82.3 \mathrm{~cm}$.

Analyzing the structure of the yield, the following conclusion can be made that the maximum height of a piece of wheat has been noted in the fourth variant, it was $9.9 \mathrm{~cm}$. in other variants that were studied the height of a piece of wheat ranged from $8,0 \mathrm{~cm}$ and on the fifth variant it was up to $9.5 \mathrm{~cm}$ at the control time (table 1).

No. 3 and 6 were pointed out for a number of pieces of wheat, they reached 18-19 items; No. 2 and 3 had 17 spikelets in a piece of wheat if leveled with the control variant. The fifth variant demonstrated the tendency of the indicator decrease.

Concerning the number of grains in a piece of wheat we can note an increase from 34 grains in the fifth variant up to 38 in the sixth one. The control variant, No. 2 and 4 there were formed 36 grains in a piece of wheat. No. 3 and 6 exceeded the variant without fertilizers by 1-2 grains in a piece of wheat; the rest variant were at the control level, with one exception No. 5 which contained 34 grains in a piece of wheat.

The maximum grain mass was documented in No. 4 and 6 variants, it was $1.37-1.36 \mathrm{~g}$. Respectively. This value is higher the control variant by $0,35-0,34 \mathrm{~g}$. In No. 2 and 3 the gain mass accounted to $1.10-1.12 \mathrm{~g}$; the decrease in the grain mass that was lower the variant without fertilizers was noted in No 5 . 
TABLE I. Yield Structure Of NOVOSIBIRSKAY 32 DEPENDING ON THE EXPERIMENT VARIANT, 2014-2017

\begin{tabular}{|c|c|c|c|c|c|}
\hline Experiment variant & $\begin{array}{l}\text { Height of a } \\
\text { piece of wheat, } \\
\text { cm }\end{array}$ & $\begin{array}{l}\text { Number of spikelets in } \\
\text { a piece of wheat, items }\end{array}$ & $\begin{array}{l}\text { Number of grains in } \\
\text { a piece of wheat, } \\
\text { items }\end{array}$ & $\begin{array}{l}\text { Mass of grains } \\
\text { from one piece of } \\
\text { wheat, } g\end{array}$ & $\begin{array}{l}\text { Mass of } \\
1000 \text { grains, } \\
\text { g }\end{array}$ \\
\hline Control (without fertilizers) & 9.5 & 17 & 36 & 1.02 & 28.5 \\
\hline Carbamide (60 kg/ha ai.) & 8.2 & 17 & 36 & 1.10 & 30.4 \\
\hline $\begin{array}{l}\text { Carbamide encapsulated within "Si" } \\
\text { technology ( } 60 \mathrm{~kg} / \mathrm{ha} \text { ai. })\end{array}$ & 9.0 & 19 & 37 & 1.12 & 30.3 \\
\hline $\begin{array}{l}\text { Carbamide encapsulated within "Si" } \\
\text { technology ( } 30 \mathrm{~kg} / \mathrm{ha} \text { ai. })\end{array}$ & 9.9 & 17 & 36 & 1.36 & 37.8 \\
\hline $\begin{array}{l}\text { Carbamide encapsulated within "Si" } \\
\text { technology }(60 \mathrm{~kg} / \mathrm{ha} \text { ai. })+\mathrm{KCl}(30 \mathrm{~kg} / \mathrm{ha} \text {. ai. })\end{array}$ & 8.0 & 16 & 34 & 1.00 & 33.3 \\
\hline $\begin{array}{l}\text { Carbamide encapsulated within "Si" } \\
\text { technology ( } 60 \mathrm{~kg} / \mathrm{ha} \text { ai. })+\mathrm{KCl}(30 \mathrm{~kg} / \mathrm{ha} \text {. ai. }) \\
+\mathrm{P}_{2} \mathrm{O}_{5}(40 \mathrm{~kg} / \mathrm{ha} \text { ai. })\end{array}$ & 9.2 & 18 & 38 & 1.37 & 36.5 \\
\hline
\end{tabular}

The mass of 1000 grains has changed depending upon the experiments to be applied. The values of changes ranged from $28,5 \mathrm{~g}$. in the control variant up to $37,8 \mathrm{~g}$. in No. 4 . It should be noted that No. 6, where the mass of 1000 grains also exceeded the control variant by $9,03 \mathrm{~g}$. all variants under study exceeded the control one (without fertilizers) by 1,8-8,0g.

In general, regarding the structure of winter wheat yield for the years when the experiment was being conducted, we noted No. 3, 4 and 6 variants, where there is observed the exceedance of the control variant (without fertilizers) in soimportant indicators as the length of a piece of wheat, ear grain content, the mass of 1000 grains and the mass of grains from one piece of wheat.

In 2014-2015 the maximum yield was noted in No. 4 with carbamide encapsulated within Si technology (30 kg/ha ai.) and it amounted to $2,73 \mathrm{kilo} / \mathrm{ha}$. Some drops in yield there were noted No. 5, 3 and 6 variants in by $0.45 ; 0.37$ and 0.31 kilo/ha respectively. No. 2 demonstrates not significant exceedance of the control variant, by $0,17 \mathrm{kilo} / \mathrm{ha}$.

In warmer weather, in 2016-2017, the maximum yield was noted in the experiment 4,58 kilo/ha when No. 6 applied, that exceeded the control variant by 0,71 kilo/ha.

The significant increase in yield we gained in No. 3, 4, 5 and 6: the exceedance over the control one by $0,19-0,49$ kilo/ha. The exception was in No. 2 carbamide $(60 \mathrm{~kg} / \mathrm{ha}$ ai.) where there was observed the tendency to the yield fall by 0,13 kilo/ha (table 2).

On average for the years of conducting the experimental study, the maximum yield was gained in No. 6, where the carbamide encapsulated within Si technology was added (N $(60 \mathrm{~kg} / \mathrm{ha}$ ai. $)+\mathrm{KCl}(30 \mathrm{~kg} / \mathrm{ha}$ ai. $)+\mathrm{P} 2 \mathrm{O} 5(40 \mathrm{~kg} / \mathrm{ha}$ ai. $))$ and it amounted to $3.55 \mathrm{kilo} / \mathrm{ha}$, that exceeds the control variant by $0.51 \mathrm{kilo} / \mathrm{ha}$, and equals to $16.81 \%$ of the yield growth.

The yield numbers in No. 3, 4 and 5 were close to the maximum one and it amounted to $3.36-3.41 \mathrm{kilo} / \mathrm{ha}$, that is higher by $0.27-0.32 \mathrm{kilo} / \mathrm{ha}$ than the control variant is $(3.04$ kilo/ha).

TABLE II. FERTILIZERS INFLUENCE ON WINTER WHEAT YIELD, $\mathrm{KILO} / \mathrm{HA}$

\begin{tabular}{|c|c|c|c|c|c|}
\hline \multirow{2}{*}{ Experiment variant } & \multicolumn{3}{|c|}{ Yield, kilo/ha } & \multicolumn{2}{c|}{ Growth } \\
\cline { 2 - 6 } & $\begin{array}{c}2014- \\
2015\end{array}$ & $\begin{array}{c}2016- \\
2017\end{array}$ & Average & kilo/ha & $\%$ \\
\hline $\begin{array}{c}\text { Control (without } \\
\text { fertilizers) }\end{array}$ & 2.20 & 3.87 & 3.04 & - & - \\
\hline Carbamide (60 kg/ha ai.) & 2.37 & 3.74 & 3.06 & 0.02 & 0.66 \\
\hline $\begin{array}{c}\text { Carbamide encapsulated } \\
\text { within "Si" technology } \\
\text { (60 kg/ha ai.) }\end{array}$ & 2.57 & 4.14 & 3.36 & 0.32 & 10.53 \\
\hline $\begin{array}{c}\text { Carbamide encapsulated } \\
\text { within "Si" technology } \\
\text { (30 kg/ha ai.) }\end{array}$ & 2.73 & 4.09 & 3.41 & 0.27 & 8.89 \\
\hline $\begin{array}{c}\text { Carbamide encapsulated } \\
\text { within "Si" technology } \\
\text { (60 kg/ha ai.) }+ \text { KCl (30 } \\
\text { kg/ha. ai.) }\end{array}$ & 2.65 & 4.06 & 3.36 & 0.32 & 10.53 \\
\hline $\begin{array}{c}\text { Carbamide encapsulated } \\
\text { within "Si" technology } \\
\text { (60 kg/ha ai.) + KCl (30 } \\
\text { kg/ha. ai.) + P2O (40 } \\
\text { kg/ha ai.) }\end{array}$ & 2.51 & 4.58 & 3.55 & 0.51 & 16.78 \\
\hline
\end{tabular}

Among all studied variants, No. 2 turned to be less effective when we added carbamide $(60 \mathrm{~kg} / \mathrm{ha}$ ai.) and in numbers we gained $3.06 \mathrm{kilo} / \mathrm{h}$, that practically equals to the control level. 
Nitrogenous fertilizers allowed to increase the yield of winter wheat, except the variant with carbamide $(60 \mathrm{~kg} / \mathrm{ha}$ ai.)
- $0.02 \mathrm{kilo} / \mathrm{ha}$. In general, all studied variants brought the exceedance in yield from $0.66 \%$ to $16.81 \%$.

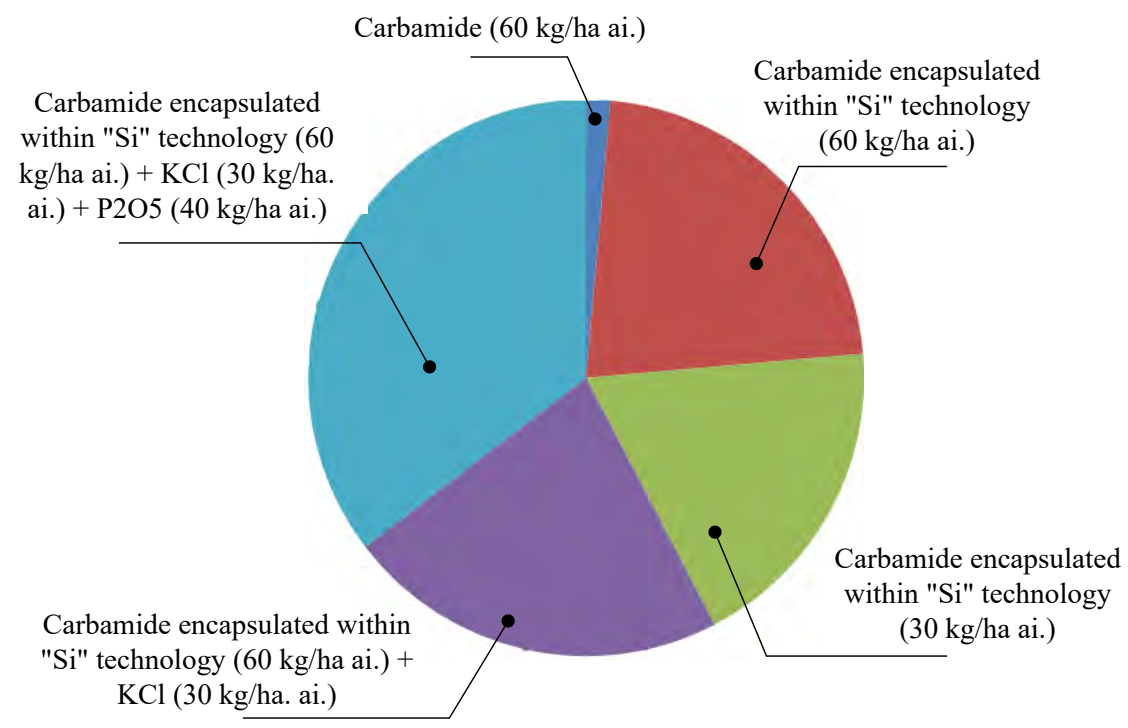

Fig. 1. Growth in yield depending on experiment variant, \%

The growth of winter wheat in the experiment variants is introduced in fig. 1 .

\section{CONCLUSION}

Natural and climatic conditions during the years of conducting the experiment and the fertilizers to be used showed that the largest leaf area was formed in the earing phase, when using No. 6 and it amounted to 46.17 kilo $\mathrm{m} 2 / \mathrm{ha}$, which is 4.73 kilo $\mathrm{m} 2 /$ ha more compared to the control variant. No. 3, 4 and 6 were pointed out for the best indicators regarding the yield structure. Thus, the yield of winter wheat, depending on the weather conditions of a winter period, can vary from 2.20 to $4.58 \mathrm{kilo} / \mathrm{ha}$, with a yield increase of up to $0.51 \mathrm{kilo} / \mathrm{ha}$, which can positively affect the economic efficiency of cultivation and distribution of this crop in the Northern forest-steppe of the Tyumen region.

Consequently, it was stated that the maximum yield growth compared to the control level took place in No. 6 (carbamide encapsulated within "Si" technology $(60 \mathrm{~kg} / \mathrm{ha}$ ai.) $+\mathrm{KCl}(30 \mathrm{~kg} / \mathrm{ha}$. ai. $)+\mathrm{P}_{2} \mathrm{O}_{5}(40 \mathrm{~kg} / \mathrm{ha}$ ai. $\left.)\right)$ and it amounted to $16.81 \%$.

\section{References}

[1] A.S. Ivanenko, N.A. Ivanenko, "Winter wheat and triticale - a powerful reserve for increasing the yield of fields of the Tyumen region", Agrarian Bulletin of the Urals, 2011, vol.. 9 (101), pp. 6-7.

[2] I.I. Gureyev, "Fertilizer of winter wheat and the method of functional diagnostics of plant nutrition", Agriculture, 2009, vol. 4, pp. 18-20.

[3] N.I. Mamsirov, "The influence of mineral fertilizers on the productivity of winter soft wheat varieties Goryanka and Maykopchanka", In Proc. Coll. scientific report All-Russian scientific-practical, June 23-24, 2015. Voronezh: Origins,.pp. 157-160. [Conference dedicated to the International soil year "Stone steppe", 2015]
[4] G.P. Pogudin, O.A. Rich, The influence of fertilizers and ameliorants on the nutritional regime of the soil and the yield of winter wheat, Agriculture, 2007, no. 3, pp. 16-18.

[5] G.L. Aslanov, "Effect of mineral fertilizers on the yield of winter wheat", Achievements of science and technology of agrarian and industrial complex, 2006, no. 10, pp. 30-31.

[6] K.N. Nevolina, The influence of minerals on the yield and grain quality of winter crops in the Cis-Urals, extend. abstr. of thesis for cand. Of agriculture,. Perm, 2012, p. 16

[7] A.S. Bashkov, G.P. Juin, I.A. Kutuzov, "The influence of systemic use of mineral fertilizers on the yield of winter rye", In Proc. of the AllRussian. scientific-practical Conf. Izhevsk: Izhevsk State Agricultural Academy, 2012, pp. 93-97. [Agrochemistry in the Pre-Urals: history and modernity dedicated to the 55th anniversary of the Department of Agrochemistry and Soil Science, 2012]

[8] A.M. Artyushin, I.P. Deryugin, A.N. Kulyukin, B.A. Yagodin, Fertilizer in intensive crop cultivation technologies. Moscow: Agropromim, 1991, p. 223

[9] I.G. Bannov, "The effect of mineral fertilizers on the yield and grain quality of winter wheat varieties in the subzone of ordinary chernozems of the Volgograd region", In proc. Volgograd: Volgograd state agricultural academy, 2005, pp. 3-4. [IX Conference for young researchers of Volgograd region, 2005]

[10] A.A. Karmatsky, K.V. Moiseeva, A.A. Moiseyev, "The effect of nitrogen fertilizers on the grain yield of winter wheat in the conditions of the Northern Trans-Urals", In Proc., November 10, 2015, Kurgan,p p. 42-43. [Advances of scientific, creative and innovative activity of youth materials VII All-Russian. scientific practical correspondence conf. young scientists, 2015]

[11] D.I .Eremin, "Changes in the content and quality of humus in agricultural use of chernozem of the leached forest-steppe zone of Zauralye", Soil science, 2016, no. 5, pp. 584-592.

[12] B.A. Bronevoy, Methods of field experience, Moscow: Agroproizdat, 1985, p. 351

[13] N.V. Perfilyev, O.A. View, "The effect of the use of fertilizer mixtures on the biometric indicators of spring wheat and the efficiency of their cultivation", Siberian Bulletin of Agricultural Sciences, 2017, no. 1, pp. 12-18.

[14] E.V. Agafonov, A.A. Gromakov, M.V. Maksimenko, "The use of complex fertilizers and nitrogen fertilization for winter wheat", Agriculture, 2012, no. 7, p. 16. 
[15] N.M. Belous, V.E. Torikov, "The strategy of innovative development of scientific research in the Bryansk State Agricultural Academy", Bulletin of the Bryansk State Agricultural Academy, 2010, no. 2, pp. 4-16. 